\title{
DIVERSITY AND POPULATION DYNAMIC OF Tabanidae (Insecta: Diptera) IN THE CERRADO-PANTANAL ECOTONE
}

\author{
DIVERSIDADE E DINÂMICA POPULACIONAL DE TABANÍDEOS (Insecta: \\ Diptera) NO ECÓTONO CERRADO-PANTANAL
}

\author{
Wilson Werner KOLLER'ㄹ ; Antonio Thadeu Medeiros de BARROS'; \\ Paulo Eduardo TEODORO² \\ 1. Embrapa Gado de Corte, Campo Grande, MS, Brasil; 2. Universidade Federal de Mato Grosso do Sul, Chapadão do Sul, \\ MS, Brasil. eduteodoro@ hotmail.com
}

\begin{abstract}
Tabanid (Diptera) species are associated with the mechanical transmission of several pathogens to both domestic and wild animals around the world. The aim of this study was to evaluate the diversity, abundance, and seasonal dynamic of tabanids in the Cerrado-Pantanal ecotone in Miranda, state of Mato Grosso do Sul, Brazil. Tabanids were collected once a month, from June 2001 to May 2003, for seven consecutive days per collection, using canopy and nzi type traps baited with a chemical attractant (1-octen-3-ol). A total of 6,492 individuals from 39 species and 18 genera was collected, which increases from 25 to 34 the number of tabanid species reported for the studied region. Tabanus occidentalis Linnaeus, $1758(62.21 \%)$ was the most abundant species throughout the collection period, followed by Lepiselaga crassipes (Fabricius, 1805) (7.19\%) and Tabanus sorbillans Wiedemann, 1828 (5.68\%). The peak of the tabanid population was reached during the rainy season, which is the period of the highest potential risk of mechanical transmission of pathogens by these insects in the studied region.
\end{abstract}

KEYWORDS: Canopy trap. Horsefly. Nzi trap. Seasonality

\section{INTRODUCTION}

Hematophagous dipterans of the Tabanidae family, known in most regions of Brazil as "mutucas," have epidemiological importance due to their association with the mechanical transmission of pathogens, including bacteria, helminths, protozoa, and viruses, to both domestic and wild animals (FOIL, 1989). In the Pantanal wetland, Brazil, horseflies of the genus Tabanus Linnaeus, 1758 , as well as the common vampire bat Desmodus rotundus Geoffroy, 1810 (Chiroptera: Phyllostomidae) are reported as vectors of Trypanosoma evansi Steel, 1884 (Trypanosomatida: Trypanosomatidae) in the white-lipped peccary (Tayassu pecari Link, 1795; Artiodactyla: Tayassuidae) and the wild pig (Sus scrofa Linnaeus, 1758; Artiodactyla: Suidae), (HERRERA et al., 2005). Tabanus nebulosus DeGeer, 1776 is associated with the transmission of Trypanosoma vivax to cattle in South America (OTTE; ABUABARA, 1991) and tabanid with $T$. vivax in the Colombian Atlantic coast (OTTE et al., 1994) and the Pantanal region, Brazil (MARTINS et al.,
2008). Besides the mechanical transmission of pathogens, the nuisance and damage caused by horseflies also lead to livestock economic losses (FOIL; HOGSETTE, 1994).

The diversity of tabanids in the Pantanal (Nhecolândia sub-region) of the state of Mato Grosso do Sul, Brazil is well-know. Important aspects of the ecology and vectorhost interaction (BARROS; FOIL, 1999, 2007; BARROS, 2001), besides the taxonomic key of these pests (BARROS; GORAYEB, 1996), are also well-known.

Investigations on vector ecology are essential to develop strategies for preventing and/or controlling diseases on livestock in the studied region. The aims of this study were: 1) to survey tabanids; and 2) to identify the species name with collections carried out in a transition area between the Pantanal and Cerrado biomes, Brazil. The results obtained were utilized to evaluate the diversity, abundance, and seasonal behavior of this insect group in the studied region. 


\section{MATERIAL AND METHODS}

\section{Characteristic of study area}

The study was conducted from June 2001 to May 2003, at the Guaicurus Ranch $\left(20^{\circ} 6^{\prime} \mathrm{S}, 56^{\circ} 48^{\prime} \mathrm{W}\right)$, located in a transition area between the Cerrado and Pantanal biomes (Miranda subregion), in the municipality of Miranda, state of Mato Grosso do Sul, Brazil. Pantanal is a seasonally flooded flat area that comprises about $140,000 \mathrm{~m}^{2}$. The region is located to the west of the state of Mato Grosso do Sul and the southwest of the state of Mato Grosso, Brazil, and to the eastern border of Bolivia and northern Paraguay (ALLEM; VALLS, 1987). The altitude is of approximately $100 \mathrm{~m}$ above sea level, and its vegetation is influenced by surrounding biomes, such as the Amazon, Atlantic Forest, Cerrado, and Paraguayan Chaco.

Cerrado represents $25 \%$ of the Brazilian territory, mostly in the Central Plateau. This biome is distributed throughout the states of Bahia, Goiás, Mato Grosso, Mato Grosso do Sul, Minas Gerais, and Tocantins, besides the Federal District, with fragments in the states of Maranhão, Pará, Piauí, Rondônia, Roraima, and São Paulo (RESENDE; GUIMARÃES, 2007). Cerrado's vegetation is mostly comprised by grasses interspersed with trees and shrubs with twisted trunks and thick barks. In the CerradoPantanal ecotone, the rainy season follows the Brazilian Midwest pattern, which occurs from October to April. Although the study area does not flood during the rainy season, its water table is superficial, and the field capacity usually saturates during that season.

\section{Collections and tabanid species name identification}

Tabanids were collected using canopy (HRIBAR et al., 1991) and nzi (MIHOK, 2002) type traps, with three units per type. Traps were made using a 2-L pet bottle. The bottles were horizontally fixed to a pet funnel placed on the top opening of the bottles. A black beach ball (40 $\mathrm{cm}$ diameter) was suspended above the canopy-type traps as a visual target for the insects. The chemical attractant 1-octen-3-ol (Merck, Millipore) (TAKKEN; KLINE, 1989) was placed in all traps; this compost was placed in vials $(5 \mathrm{~mL})$ with a perforated lid pierced by a pipe cleaning rod and replaced when necessary.
The traps were installed in open areas of native grasses, approximately $10 \mathrm{~m}$ from wooded areas ["cerradão", remaining riparian or riparian forest, and/or a Scheelea phalerata (Mart. ex Spreng.; Arecales: Arecaceae) community], protected from cattle invasion by a square wire-fence ( $4 \mathrm{~m}$ side).

Trappings were conducted once a month each, for seven days, with daily removal of insects from traps. A cotton ball treated with ethyl-acetate was placed inside the collecting bottles after removed from traps; then, dead insects were transferred to plastic bags labeled according to the sample. Tabanids were identified using taxonomic keys such as type of wing, oral device, and legs (WILKERSON, 1979; BARROS; GORAYEB, 1996) and the species name was confirmed by Dr. Inocêncio Gorayeb (Museu Paraense Emílio Goeldi, Belém, state of Pará, Brazil). The specimens were mounted and deposited into the entomological collection of Embrapa Pantanal, in Corumbá, state of Mato Grosso do Sul, Brazil. Data regarding the air temperature $\left({ }^{\circ} \mathrm{C}\right)$, $\mathrm{RH}(\%)$, and rainfall $(\mathrm{mm})$ were obtained from the nearest weather stations.

\section{Statistical Analysis}

Data regarding the tabanid collections were analyzed using descriptive analyses by seasonal distribution, trap type, and frequency of individuals of the most abundant species. The negative effect of weather conditions (mean temperature, relative humidity, and rainfall) during the interval between collections (approximately three weeks) on the tabanid abundance was analyzed by the Pearson correlation. All analyses were performed using the R statistical software.

\section{RESULTS AND DISCUSSION}

The rainy and dry seasons were typical for the region during the first year of study. However, the dry season was longer in the second year (Figure 1). A total of 6,492 tabanid individuals, belonging to 39 species and 18 genera, was collected (Table 1). The most representative genera were Tabanus (13 species) and Chrysops (four species), which is similar to the results found in the Pantanal (Nhecolândia sub-region), state of Mato Grosso do Sul, Brazil (BARROS \& GORAYEB, 1996). The diversity of tabanid species found in the Cerrado-Pantanal ecotone $(n=39)$ was higher 
than that detected in the Pampa biome, Brazil (KRÜGER; KROLOW, 2015) and lower than that observed in Eastern (GORAYEB, 1993) and Central Amazon (FERREIRA-KEPPLER et al., 2010), Brazil. The number of tabanid species increased from 25 (BARROS; GORAYEB, 1996) to 34 species for the state of Mato Grosso do Sul, Brazil. Three unknown species obtained from collections carried out in this study were described: Myiotabanus amazonicus Rafael \& Ferreira, 2004 (RAFAEL; FERREIRA, 2004); Pityocera barrosi Gorayeb \& Krolow, 2015; and Pityocera rhinolissa Krolow \& Henriques, 2015 (KROLOW et al., 2015).

Most tabanid species $(71.79 \%)$ from the Cerrado-Pantanal ecotone showed a relative abundance (RA) lower than $1.00 \%$, representing $4.08 \%$ of the total species collected. Three species, with RA above $5.00 \%$, represented $75.05 \%$ of the total number of tabanids collected in the study (Table 1). A high frequency of the less abundant species (RA $<1.00 \%$ ) was also reported in the Brazilian Amazon (GORAYEB, 1993; FERREIRAKEPLER et al., 2010) and in the Pantanal (Nhecolândia sub-region), Brazil (BARROS; FOIL, 1999).

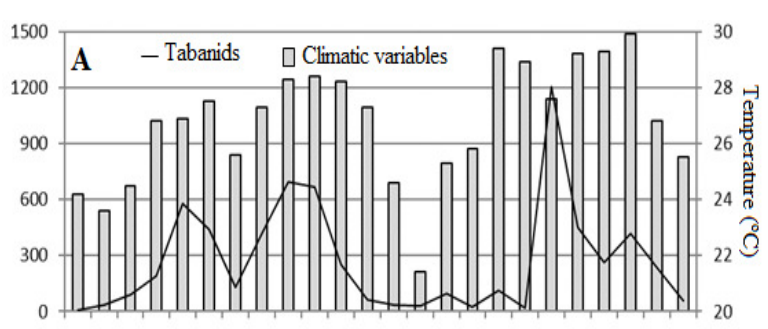

The most abundant tabanid species in the Cerrado-Pantanal ecotone was Tabanus occidentalis Linnaeus, 1758 (62.2\%), followed by Lepiselaga crassipes Fabricius, 1805 (7.2\%), and Tabanus sorbillans Wiedemann, 1828 (5.7\%). Tabanus importunus Wiedemann, 1828 (29.5\%), T. occidentalis (25.4\%), Tabanus claripennis Bigot, 1892 (12.3\%), and L. crassipes $(7.5 \%)$ were the most abundant species collected in a survey conducted at the Pantanal (Nhecolândia sub-region), Brazil (BARROS; FOIL, 1999).

The relative abundance of $T$. occidentalis in the Cerrado-Pantanal transition environment was over twice as much as that reported in the Pantanal and three to four times as much as that reported in the Amazon (GORAYEB, 1993; FERREIRA-KEPLER et al., 2010), Brazil, suggesting a possible adaptation of this species to the dry condition of the Cerrado biome, Brazil. Although $T$. importunus was relatively abundant in the Pantanal biome, it was not common near the Cerrado biome (3.28\%), as evidenced by the collection using canopy (4.56\%) and nzi $(0.26 \%)$ type traps (Table 2$)$. Similarly, $T$. claripennis was more abundant in the Pantanal $(12.30 \%)$ than in transition areas of PantanalCerrado (3.92\%).

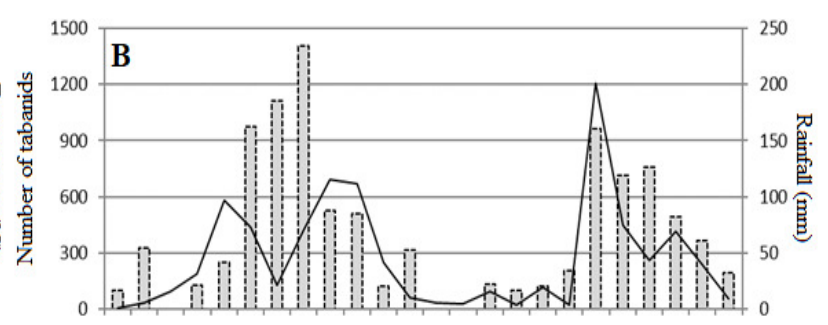

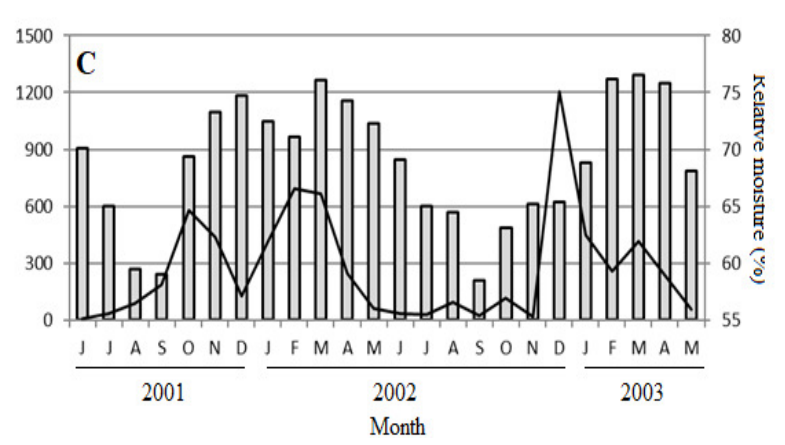

Figure 1. Seasonal fluctuation of Tabanidae (Diptera) and relation of this parameter with weather in a transition area between Cerrado and Pantanal biomes, municipality of Miranda, Mato Grosso do Sul state, Brazil from June 2001 to May 2003. 
Table 1. Number of tabanid (Diptera) individuals per species collected per month and total besides relative abundance (RA) using canopy and nzi type traps, in a transition area between Cerrado and Pantanal, municipality of Miranda, Mato Grosso do Sul state, Brazil from June 2001 and May 2003.

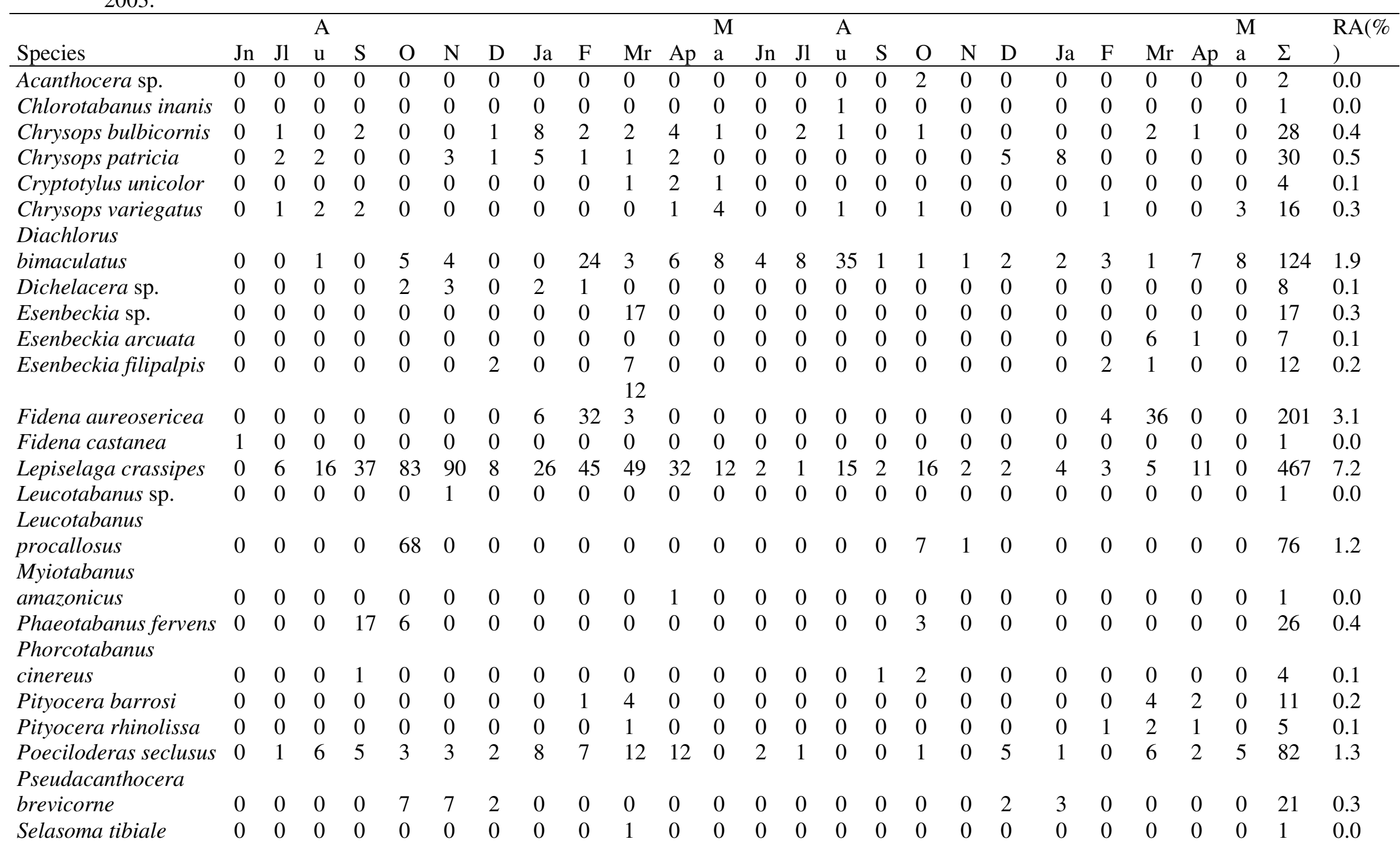


Stypommisa sp.

Stypommisa

$\begin{array}{llll}0 & 0 & 0 & 0\end{array}$

rubrithorax

Tabanus claripennis

Tabanus guyanensis

Tabanus importunus

Tabunus nebulosus

Tabanus nebulosus

ornativentris

$\begin{array}{lllllllllllllllllllllllllllll}0 & 1 & 12 & 0 & 0 & 0 & 0 & 0 & 0 & 0 & 0 & 0 & 0 & 0 & 0 & 0 & 0 & 0 & 0 & 0 & 0 & 0 & 0 & 0 & 13 & 0.2\end{array}$

$\begin{array}{lllllllllllllllllllllllllllll}4 & 9 & 13 & 45 & 21 & 7 & 3 & 10 & 18 & 10 & 1 & 2 & 4 & 5 & 7 & 6 & 10 & 2 & 68 & 21 & 20 & 12 & 6 & 8 & 312 & 4.8\end{array}$

$\begin{array}{llllllllllllllllllllllllllllll}0 & 0 & 0 & 0 & 0 & 0 & 0 & 0 & 0 & 0 & 0 & 0 & 0 & 0 & 0 & 0 & 0 & 0 & 0 & 0 & 1 & 0 & 0 & 0 & 1 & 0.0\end{array}$

$\begin{array}{lllllllllllllllllllllllllllll}0 & 1 & 2 & 3 & 16 & 27 & 0 & 16 & 57 & 8 & 1 & 1 & 1 & 4 & 1 & 0 & 17 & 8 & 24 & 23 & 0 & 0 & 2 & 1 & 213 & 3.3\end{array}$

$\begin{array}{lllllllllll}0 & 0 & 1 & 5 & 3 & 2 & 2 & 1 & 0 & 0 & 0 \\ & & & & 33 & 20 & & 31 & 45 & 36 & 13\end{array}$

$\begin{array}{lll}0 & 0 & 3\end{array}$

5

$\begin{array}{llllllll}0 & 0 & 0 & 0 & 0 & 0 & 22 & 0.3 \\ 108 & 32 & & 29 & 15 & & 403 & \end{array}$

$\begin{array}{llllllllllllllllllllllllllll}\text { Tabanus occidentalis } & 1 & 11 & 33 & 60 & 5 & 1 & 55 & 7 & 0 & 2 & 4 & 28 & 20 & 8 & 25 & 9 & 34 & 3 & 4 & 4 & 75 & 0 & 7 & 22 & 8 & 62.2\end{array}$

Tabanus palpalis

Tabanus

pseudonebulosus

Tabanus pungens

Tabanus sorbillans

Tabanus triangulum

Tabanus wilkersoni

Tabanus wokei

$\begin{array}{lllllllllllllllllll}0 & 0 & 0 & 0 & 2 & 16 & 31 & 5 & 4 & 23 & 18 & 0 & 0 & 0 & 0 & 0 & 1 & 0 & 3\end{array}$

10

Undetermined species

\begin{tabular}{lllllllllllllllllllllllllllll}
0 & 0 & 0 & 1 & 1 & 0 & 0 & 0 & 0 & 0 & 0 & 0 & 0 & 0 & 0 & 0 & 0 & 0 & 0 & 0 & 0 & 0 & 0 & 0 & 2 & 0.0 & 0 \\
0 & 0 & 0 & 1 & 1 & 1 & 0 & 0 & 1 & 0 & 0 & 0 & 0 & 0 & 1 & 1 & 0 & 0 & 3 & 3 & 2 & 1 & 0 & 1 & 16 & 0.3 & \\
0 & 0 & 0 & 0 & 10 & 41 & 19 & 8 & 47 & 45 & 35 & 3 & 0 & 0 & 0 & 0 & 10 & 2 & 5 & 37 & 39 & 34 & 27 & 7 & 369 & 5.7 & \\
0 & 0 & 0 & 0 & 0 & 0 & 0 & 0 & 0 & 0 & 0 & 0 & 0 & 0 & 1 & 0 & 0 & 0 & 0 & 0 & 0 & 0 & 0 & 0 & 1 & 0.0 & 0 \\
0 & 0 & 0 & 0 & 0 & 0 & 0 & 0 & 0 & 0 & 0 & 1 & 0 & 0 & 0 & 0 & 0 & 0 & 0 & 0 & 0 & 0 & 0 & 0 & 1 & 0.0 \\
0 & 0 & 3 & 1 & 0 & 1 & 0 & 1 & 0 & 0 & 0 & 0 & 0 & 0 & 1 & 0 & 0 & 0 & 1 & 0 & 0 & 0 & 0 & 0 & 8 & 0.1 \\
0 & 0 & 0 & 1 & 0 & 0 & 1 & 0 & 0 & 0 & 1 & 0 & 0 & 0 & 0 & 0 & 0 & 0 & 3 & 0 & 0 & 0 & 1 & 0 & 7 & 0.1 \\
\hline
\end{tabular}

Total $\begin{array}{lllllllllllllllll}6 & 33 & 91 & 8 & 9 & 9 & 8 & 8 & 2 & 9 & 0 & 61 & 33 & 29 & 95 & 22 & 5\end{array}$ 197 $\begin{array}{llllll}9 & 0 & 7 & 6 & 56 & 2\end{array}$

Jn-June, Jl-July, Au-August, S-September, O-October, $\quad$ N-November, $\quad$ D-December, Ja-January, F-February, Mr-March, Ap-April, Ma-May. 
Table 2. Frequency of tabanids (Diptera) collected using canopy and nzi type traps in a transition area between Cerrado and Pantanal in Miranda, Mato Grosso do Sul state, Brazil from June 2001 to May 2003.

\begin{tabular}{|c|c|c|c|c|c|c|}
\hline \multirow[b]{2}{*}{ Species } & \multicolumn{2}{|c|}{ Canopy } & \multicolumn{2}{|l|}{ Nzi } & \multirow{2}{*}{$\begin{array}{l}\text { Canopy } \\
\mathrm{n} \\
\end{array}$} & \multirow{2}{*}{$\begin{array}{l}+\mathrm{Nzi} \\
\%\end{array}$} \\
\hline & $\mathrm{n}$ & $\%$ & $\mathrm{n}$ & $\%$ & & \\
\hline Acanthocera sp. & 2 & 0.04 & 0 & 0.00 & 2 & 0.03 \\
\hline Chlorotabanus inanis & 1 & 0.02 & 0 & 0.00 & 1 & 0.02 \\
\hline Chrysops bulbicornis & 28 & 0.61 & 0 & 0.00 & 28 & 0.43 \\
\hline Chrysops patricia & 30 & 0.66 & 0 & 0.00 & 30 & 0.46 \\
\hline Chrysops variegatus & 13 & 0.28 & 3 & 0.16 & 16 & 0.25 \\
\hline Cryptotylus unicolor & 4 & 0.09 & 0 & 0.00 & 4 & 0.06 \\
\hline Diachlorus bimaculatus & 80 & 1.75 & 44 & 2.28 & 124 & 1.91 \\
\hline Dichelacera sp. & 1 & 0.02 & 7 & 0.36 & 8 & 0.12 \\
\hline Esenbeckia sp. & 9 & 0.20 & 8 & 0.41 & 17 & 0.26 \\
\hline Esenbeckia arcuata & 2 & 0.04 & 5 & 0.26 & 7 & 0.11 \\
\hline Esenbeckia filipalpis & 0 & 0.00 & 12 & 0.62 & 12 & 0.18 \\
\hline Fidena aureosericea & 201 & 4.41 & 0 & 0.00 & 201 & 3.10 \\
\hline Fidena castanea & 1 & 0.02 & 0 & 0.00 & 1 & 0.02 \\
\hline Lepiselaga crassipes & 421 & 9.23 & 46 & 2.38 & 467 & 7.19 \\
\hline Leucotabanus sp. & 1 & 0.02 & 0 & 0.00 & 1 & 0.02 \\
\hline Leucotabanus procallosus & 32 & 0.70 & 44 & 2.28 & 76 & 1.17 \\
\hline Myiotabanus amazonicus. & 1 & 0.02 & 0 & 0.00 & 1 & 0.02 \\
\hline Phaeotabanus fervens & 26 & 0.57 & 0 & 0.00 & 26 & 0.40 \\
\hline Phorcotabanus cinereus & 4 & 0.09 & 0 & 0.00 & 4 & 0.06 \\
\hline Pityocera barrosi & 1 & 0.02 & 10 & 0.52 & 11 & 0.17 \\
\hline Pityocera rhinolissa & 3 & 0.07 & 2 & 0.10 & 5 & 0.08 \\
\hline Poeciloderas seclusus & 81 & 1.78 & 1 & 0.05 & 82 & 1.26 \\
\hline Pseudacanthocera brevicorne & 19 & 0.42 & 2 & 0.10 & 21 & 0.32 \\
\hline Selasoma tibiale & 0 & 0.00 & 1 & 0.05 & 1 & 0.02 \\
\hline Stypommisa sp. & 2 & 0.04 & 1 & 0.05 & 3 & 0.05 \\
\hline Stypommisa rubrithorax & 1 & 0.02 & 12 & 0.62 & 13 & 0.20 \\
\hline Tabanus claripennis & 179 & 3.92 & 133 & 6.89 & 312 & 4.81 \\
\hline Tabanus guyanensis & 1 & 0.02 & 0 & 0.00 & 1 & 0.02 \\
\hline Tabanus importunus & 208 & 4.56 & 5 & 0.26 & 213 & 3.28 \\
\hline Tabunus nebulosus & 69 & 1.51 & 0 & 0.00 & 69 & 1.06 \\
\hline Tabanus nebulosus ornativentris & 19 & 0.42 & 3 & 0.16 & 22 & 0.34 \\
\hline Tabanus occidentalis & 2891 & 63.41 & 1147 & 59.40 & 4038 & 62.18 \\
\hline Tabanus palpalis & 60 & 1.32 & 211 & 10.93 & 271 & 4.17 \\
\hline Tabanus pseudonebulosus & 2 & 0.04 & 0 & 0.00 & 2 & 0.03 \\
\hline Tabanus pungens & 16 & 0.35 & 0 & 0.00 & 16 & 0.25 \\
\hline Tabanus sorbillans & 146 & 3.20 & 223 & 11.55 & 369 & 5.68 \\
\hline Tabanus triangulum & 1 & 0.02 & 0 & 0.00 & 1 & 0.02 \\
\hline Tabanus wilkersoni & 1 & 0.02 & 0 & 0.00 & 1 & 0.02 \\
\hline Tabanus wokei & 3 & 0.07 & 5 & 0.26 & 8 & 0.12 \\
\hline Unidentified species & 1 & 0.02 & 6 & 0.31 & 7 & 0.11 \\
\hline Total & 4561 & 100.0 & 1931 & 100.0 & 6492 & 100.0 \\
\hline
\end{tabular}


Two annual tabanid population peaks were recorded in the Cerrado-Pantanal ecotone, both related to the rainy season in the region. The first peak occurred at the beginning of the rainy season, while the second peak occurred at the end of the rainy season (February and March). A similar seasonality was found for tabanid populations from Pantanal, Brazil (BARROS; FOIL, 1999). The longer dry season (December) of the second year of study may have contributed to the tabanid
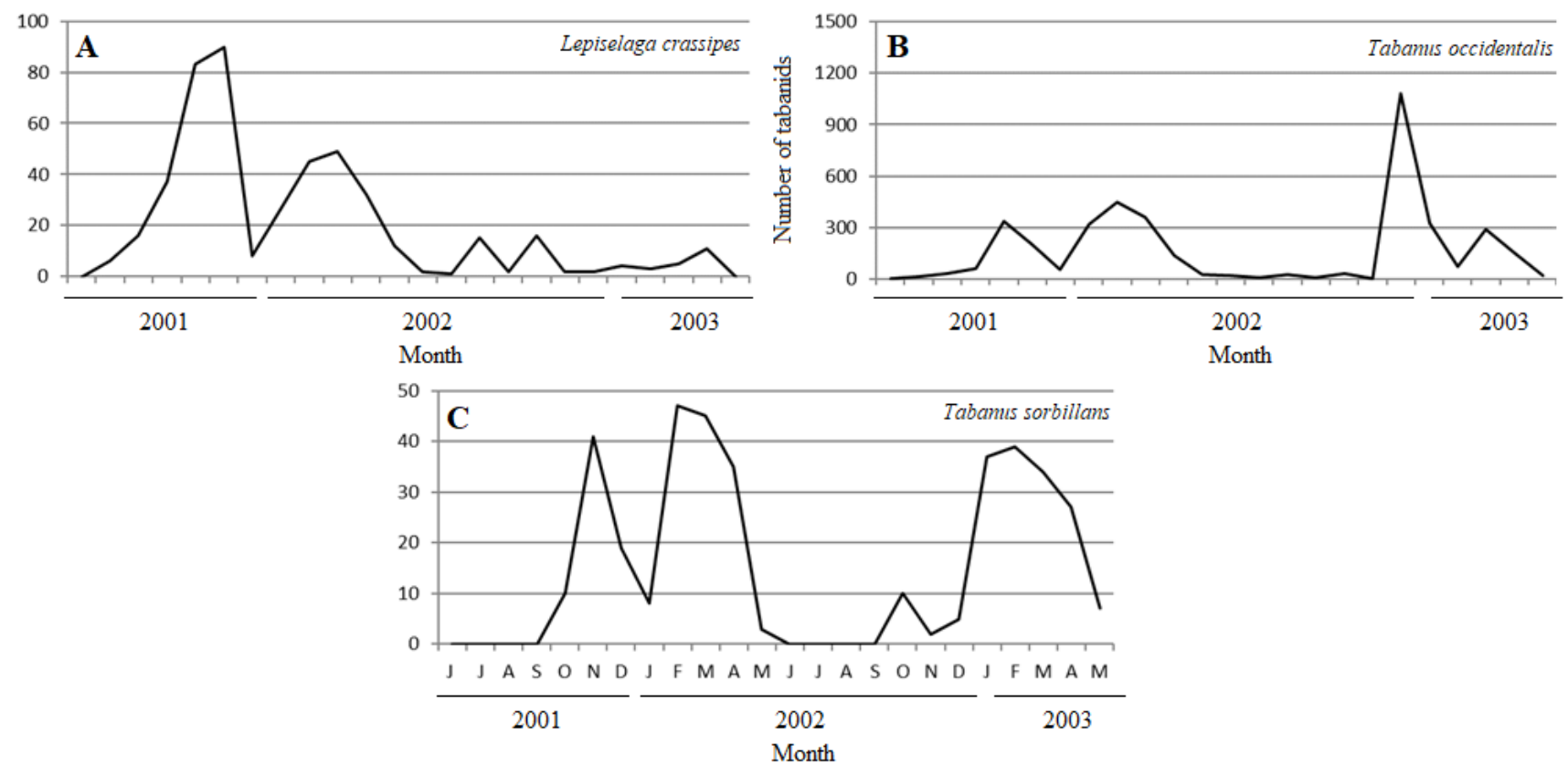

Figure 2. Population dynamics of the most abundant tabanid (Diptera) species (Lepiselaga crassipes - A, Tabanus occidentalis - B e Tabanus sorbillans - C) collected using two trap types, in the transition area between Cerrado and Pantanal in Miranda, Mato Grosso do Sul state, Brazil.

Although the relative abundance was different between the most abundant species, the seasonality of the tabanid species (Figure 2) was strongly influenced by the rainfall in the region. Except for T. sorbillans, which was not collected during the dry season, the other two species were collected throughout the year. The highest abundance of these species during the rainy season, with a subsequent decline, was similar to that observed in the Pantanal (BARROS; FOIL, 1999).

The number of specimens and species collected using the canopy type trap was higher than population peak. This longer dry season delayed the beginning of the rainy season for about two months and influenced tabanid abundance. Actually, the general seasonality of tabanids in this study was highly influenced by the most abundant species ( $T$. occidentalis) (Figure 2), which represented 62.2\% of the total collected species. The climatic variables that influenced this behavior were average monthly temperature and monthly rainfall (Table 3).

Table 3. Pearson correlation between monthly tabanid (Diptera) individuals collected and weather parameters between collections in the Cerrado-Pantanal ecotone in Miranda, Mato Grosso do Sul state, Brazil from June 2001 to May 2003.

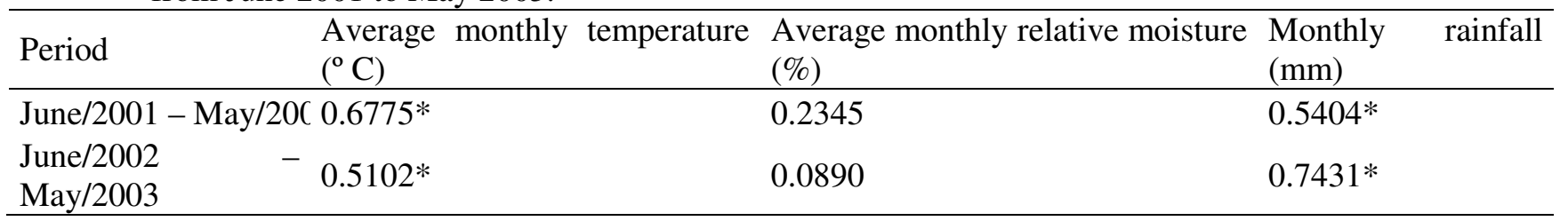

*Significant at $5 \%$ probability by the t-test. 


\section{CONCLUSION}

The diversity of tabanids in the CerradoPantanal ecotone, Brazil shows a high degree of adaptation of this insect group to both biomes. The highest abundance of these insects during the rainy season increases the risk of mechanical transmission of pathogens to both livestock and wildlife in the studied region.

\section{ACKNOWLEDGMENT}

To "Coordenação de Aperfeiçoamento de Pessoal de Nível Superior (CAPES)", "Conselho Nacional de Desenvolvimento Científico e
Tecnológico (CNPq)", "Fundação de Apoio ao Desenvolvimento do Ensino, Ciência e Tecnologia do Estado de Mato Grosso do Sul (FUNDECT)", "Embrapa Gado de Corte", and "Universidade para o Desenvolvimento do Estado e da Região do Pantanal (Uniderp) - campus Anhanguera". We are grateful to João Carlos Marson, Anselmo Ranier Pereira, Luiz Carlos Costa Alecrim, and Vergílio Amorim for logistic support. We also thank to Cláudio Roberto Madruga, Charles Ferreira Martins, Adriana Castilhos de Souza Umaki, Ernande Ravaglia, Cristina Pires de Araújo, Ana Paula Kassar Ismael, Adalberto Antônio Marques, and José Gomes de Almeida for the valuable support.

RESUMO: Tabanídeos (Diptera) são importantes vetores de patógenos a animais domésticos e silvestres no mundo. O objetivo foi estudar a diversidade, abundância e dinâmica sazonal de Tabanidae no ecótono Cerrado-Pantanal em Miranda, Mato Grosso do Sul, Brasil. Uma captura foi realizada por mês cada por sete dias consecutivos de junho 2001 a maio 2003 utilizando armadilhas modelo canopy e nzi. As armadilhas foram iscadas com o atrativo químico "1-octen-3-ol". Um total de 6.491 tabanídeos, de 39 espécies e 18 gêneros, foi capturado, ampliando a lista de espécies de tabanídeos relatados para o Mato Grosso do Sul de 25 para 34. Tabanus occidentalis Linnaeus, $1758(62,21 \%)$ foi o mais abundante durante o período de coleta, seguido por Lepiselaga crassipes (Fabricius, 1805) (7,19\%) e Tabanus sorbillans Wiedemann, 1828 (5,68\%). A maioria das espécies de tabanídeos teve pico populacional durante o período chuvoso, considerado o de maior risco potencial de transmissão mecânica de patógenos por estes vetores na região estudada.

PALAVRAS-CHAVE: Armadilha canopy. Armadilha nzi. Mutuca. Sazonalidade

\section{REFERENCES}

ALLEM, A. C.; VALLS, J. F. M. Recursos forrageiros nativos do Pantanal. Brasília: Embrapa, 1987. 339p.

BARROS, A. T. M. Seasonality and relative abundance of Tabanidae (Diptera) captured on horses in the Pantanal, Brazil. Memórias do Instituto Oswaldo Cruz, v. 96, p. 917-923, 2001.

https://doi.org/10.1590/S0074-02762001000700006

BARROS, T.; FOIL, L. D. Seasonal occurrence and relative abundance of Tabanidae (Diptera) from the Pantanal region. Memoirs on Entomology International, v. 14, p. 387-396, 1999.

BARROS, A. T. M.; FOIL, L. D. The influence of distance on movement of tabanids (Diptera: Tabanidae) between horses. Veterinary Parasitology, v. 144, p. 380-384, 2007.

https://doi.org/10.1016/j.vetpar.2006.09.041

BARROS, A. T. M.; GORAYEB, I. S. Chave de identificação para tabanídeos (Diptera: Tabanidae) do Pantanal, sub-região da Nhecolândia, Mato Grosso do Sul, Brasil. Revista Brasileira de Biologia, v. 56, p. 547-551, 1996.

FERREIRA-KEPPLER, R. L.; RAFAEL, J. A.; GUERRERO, J. C. H. Sazonalidade e uso de ambientes por espécies de Tabanidae (Diptera) na Amazônia Central, Brasil. Neotropical Entomology, v. 39, p. 645-654, 2010. https://doi.org/10.1590/S1519-566X2010000400028 
FOIL, L. D. Tabanids as vectors of disease agents. Parasitology Today, v. 5, p. 88-96, 1989. https://doi.org/10.1016/0169-4758(89)90009-4

FOIL, L. D.; HOGSETTE, J. A. Biology and control of tabanids, stable flies and horn flies. Scientific and Technical Review of the Office International des Epizooties, v. 13, p. 1125-1158, 1994. https://doi.org/10.20506/rst.13.4.821

GORAYEB, I. S. Tabanidae (Diptera) da Amazônia. XI - Sazonalidade das espécies da Amazônia Oriental e correlação com fatores climáticos. Boletim do Museu Paraense Emilio Goeldi, série Zoologia, v. 9, p. 241281, 1993.

HERRERA, H. M.; NOREK, A.; FREITAS, T. P. T.; RADEMAKER, V.; FERNANDES, O.; JANSEN, A. M. Domestic and wild mammal's infection by Trypanosoma evansi in a pristine area of the Brazilian Pantanal region. Parasitology Research, v. 96, p. 121-126, 2005. https://doi.org/10.1007/s00436-005-1334-6

HRIBAR, L. J.; LEPRINCE, D. J.; FOIL, L. D. Design for a canopy trap for collecting horse flies (Diptera: Tabanidae). Journal of the American Mosquito Control Association, v. 23, p. 657-659, 1991.

KROLOW, T. K.; HENRIQUES, A. L.; GORAYEB, I. S.; LIMEIRA-DE-OLIVEIRA, F.; BUESTÁN, J. Taxonomic revision of the neotropical genus Pityocera Giglio-Tos, 1896 (Diptera: Tabanidae: Scionini).

Zootaxa, v. 3904, p. 301-333, 2015. https://doi.org/10.11646/zootaxa.3904.3.1

KRÜGER, R.; KROLOW, T. K. Seasonal patterns of horse fly richness and abundance in the Pampa biome of Southern Brazil. Journal of Vector Ecology, v. 40, p. 364-372, 2015. https://doi.org/10.1111/jvec.12175

MARTINS, C. F.; MADRUGA, C. R.; KOLLER, W. W.; ARAÚJO, F. R.; SOARES, C. O.; KESSLER, R. H.; MELO, E. S. P.; RIOS, L. R.; ALMEIDA, R. C. F.; LIMA Jr, M. S. C.; BARROS, A. T. M.; MARQUES, L. C. Trypanosoma vivax infection dynamics in a cattle herd maintained in a transition area between Pantanal lowlands and highlands of Mato Grosso do Sul, Brazil. Pesquisa Veterinária Brasileira, v. 28, p. 51-56, 2008. https://doi.org/10.1590/S0100-736X2008000100008

MIHOK, S. The development of a multipurpose trap (the Nzi) for tsetse and other biting flies. Bulletin of Entomological Research, v. 92, p. 385-403, 2002. https://doi.org/10.1079/BER2002186

OTTE, M. J.; ABUABARA, J. Y. Transmission of South American Trypanosoma vivax by the Neotropical horsefly Tabanus nebulosus. Acta Tropica, v. 49, p. 73-76, 1991. https://doi.org/10.1016/0001706X(91)90033-G

OTTE, M. J.; ABABUARA, J. Y.; WELLS, E. A. Trypanosoma vivax in Colombia: epidemiology and production losses. Tropical Animal Health and Production, v. 26, p. 146-156, 1994.

https://doi.org/10.1007/BF02241071

RAFAEL, J. A.; FERREIRA, R. L. M. Revisão do gênero neotropical Myiotabanus Lutz (Diptera, Tabanidae) com descrição de uma espécie nova. Revista Brasileira de Zoologia, v. 21, p. 325-331, 2004. https://doi.org/10.1590/S0101-81752004000200028

RESENDE, M. L. F.; GUIMARÃES, L. L. Inventários da Biodiversidade do Bioma Cerrado: Biogeografia de Plantas. Instituto Brasileiro de Geografia e Estatística, Rio de Janeiro, 2007. 14p.

TAKKEN, W.; KLINE, D. L. Carbon dioxide and 1-octen-3-ol as a mosquito attractants. Journal of the American Mosquito Control Association, v. 5, p. 311-316, 1989.

WILKERSON, R.C. Horse flies (Diptera: Tabanidae) of the Colombian departments of Choco, Valle and Cauca. Cespedesia, v. 8, p. 99-421, 1979. https://doi.org/10.5962/bhl.title.45984 